\title{
ВЛИЯНИЕ ЭКСТРАКТА ЭХИНАЦЕИ ПУРПУРНОЙ НА СТРУКТУРУ СЛИЗИСТОЙ ОБОЛОЧКИ И КОЛИЧЕСТВО КЛЕТОК СОБСТВЕННЫХ ЖЕЛЕЗ СЛИЗИСТОЙ ОБОЛОЧКИ ФУНДАЛЬНОГО ОТДЕЛА ЖЕЛУДКА КРЫС
}

\author{
(С) Кувенёва М.Л. ${ }^{1}$, Лузин В.И. ${ }^{2}$, Морозов В.Н. ${ }^{3}$, Морозова Е.Н. ${ }^{4}$ \\ ${ }^{1}$ Кафедра биологии, ${ }^{2}$ кафедра анатомии человека, оперативной хирургии и топографической \\ анатомии Луганского государственного медицинского университета, Луганск; \\ ${ }^{3}$ кафедра анатомии человека, ${ }^{4}$ кафедра гистологии \\ Белгородского государственного национального исследовательского университета, Белгород \\ E-mail: morozov_v@bsu.edu.ru
}

\begin{abstract}
Целью исследования было изучить влияние экстракта эхинацеи пурпурной на высоту собственных желез, общее количество клеток и количество пристеночных экзокриноцитов в одной собственной железе слизистой оболочки фундального отдела желудка крыс. Эксперимент был проведен на шестидесяти половозрелых беспородных белых крысахсамцах, которые были разделены на две экспериментальные группы. Первую группу составили интактные крысы, вторую - крысы, подвергавшиеся воздействию экстракта эхинацеи пурпурной. С помощью светооптического микроскопирования с применением цифрового морфометрического комплекса проводили измерение высоты собственных желез, подсчет общего количества клеток и количества пристеночных экзокриноцитов в одной собственной железе слизистой оболочки фундального отдела желудка крыс после предварительной окраски срезов гематоксилин-эозином. Воздействие экстракта эхинацеи пурпурной приводит к увеличению изученных показателей, которое сохраняется после завершения его действия.
\end{abstract}

Ключевые слова: фундальный отдел желудка, собственная железа желудка, пристеночные экзокриноциты, экстракт эхинацеи пурпурной.

\section{INFLUENCE OF ECHINACEA PURPLE EXTRACT ON THE STRUCTURE OF THE MUCOSA AND NUMBER OF PROPER GASTRIC GLANDS CELLS OF FUNDIC MUCOSA OF RATS' STOMACH Kuvenyova M.L. ${ }^{1}$, Luzin V.I. ${ }^{2}$, Morozov V. N. ${ }^{3}$, Morozova E.N. ${ }^{4}$ \\ ${ }^{1}$ Biology Department, ${ }^{2}$ Human Anatomy, Operative Surgery and Topographic Anatomy Department of Lugansk State Medical University, Lugansk;}

${ }^{3}$ Human Anatomy Department, ${ }^{4}$ Histology Department of Belgorod State National Research University, Belgorod

The research purpose was to study the influence of echinacea purple extract on height of proper gastric glands, total amount of cells, and number of parietal cells in one proper fundus gland of rats stomach. The experiment was conducted on sixty mature outbred white male rats, divided into two experimental groups. The first group consisted of intact rats, the second one- rats having exposed to echinacea purple extract. The proper gastric gland height measurement was carried out, and the number of all cells and parietal cells in one proper fundus gland of rats`stomach was calculated with the light-optical microscopy using a digital morphometric complex after preliminary coloring the sections with hematoxylin-eosin. The echinacea purple extract application increases the studied parameters, which remains after its action has completed.

Keywords: gastric fundus, gastric gland proper, parietal cells, echinacea purple extract.

Одной из наиболее чувствительных к действию различных экзогенных факторов, постоянно оказывающих воздействие на организм человека, систем органов является пищеварительная система. Морфофункциональные изменения в желудке часто являются следствием влияния факторов окружающей среды на организм $[1,3]$. Большинство патологических процессов, в том числе и в слизистой оболочке желудка, начинается с повреждения мембран. Среди многих причин, которые приводят к повреждению мембран, важное место принадлежит процессу перекисного окисления липидов [2]. Вместе с тем интенсивность перекисного окисления липидов в значительной мере определяется состоянием антиокси- дантной защитной системы организма и его обеспечением антиоксидантами [5].

Таким образом, изучение воздействия на желудок препаратов, обладающих антиоксидантными свойствами, является актуальным вопросом.

Известно, что препараты эхинацеи пурпурной являются антиоксидантами, угнетающими интенсивность процессов свободнорадикального окисления липидов, что с успехом применяется в различных отраслях медицины [4]. Но влияние экстракта эхинацеи пурпурной (ЭЭП) на желудок изучено недостаточно. Именно поэтому целью исследования было изучить влияние ЭЭП на высоту собственных желез, общее количество клеток и количество пристеночных экзокриноцитов в одной собственной железе слизистой оболочки фундального отдела желудка крыс. 


\section{МАТЕРИАЛЫ И МЕТОДЫ ИССЛЕДОВАНИЯ}

Для эксперимента использовали шестьдесят белых крыс-самцов массой 300-350 граммов. Первую группу составили интактные крысы, а вторую - крысы, которым в течение двух месяцев пять дней в неделю с помощью зонда внутрижелудочно вводился жидкий ЭЭП (производитель: «ОАО» Лубныфарм», г. Лубны, Полтавская обл.). Введение производилось из расчета 200 мг/кг. По истечении срока эксперимента (на первые, седьмые, пятнадцатые, тридцатые и шестидесятые сутки по окончании действия ЭЭП) эвтаназию животных осуществляли путем декапитации под эфирным наркозом. С помощью светооптического микроскопирования с применением цифрового морфометрического комплекса проводили измерение высоты собственных желез, подсчет общего количества клеток и количества пристеночных экзокриноцитов в одной собственной железе слизистой оболочки фундального отдела желудка крыс после предварительной окраски срезов гематоксилин-эозином.

Данные экспортировали в программу Microsoft Excel для дальнейшей статистической обработки и хранения. Для оценки статистической значимости различий между исследуемыми показателями был использован критерий Стьюдента для независимых выборок. Во всех исследованиях уровень значимости составлял менее $5 \%(\mathrm{p}<0,05)$.

\section{РЕЗУЛЬТАТЫ ИССЛЕДОВАНИЯ И ИХ ОБСУЖДЕНИЕ}

Введение ЭЭП оказывало влияние на высоту желез слизистой оболочки фундального отдела желудка во все сроки исследования, за исключением тридцатых и шестидесятых суток, когда наблюдаемые изменения не были статистически значимыми в сравнении с высотой желез интактных крыс контрольной группы (таблица 1). На первые сутки показатель увеличивался на $28,6 \%$, на седьмые - на $28,7 \%$, на пятнадцатые - на $17,8 \%(\mathrm{p}<0,001)$.

Внутригрупповое сравнение высоты собственных желез фундального отдела желудка крыс, которым вводили ЭЭП, в разные сроки исследования показало, что в течение шестидесятисуточного периода наблюдения этот показатель постепенно уменьшался. С первых по пятнадцатые сутки высота уменьшилась на $6,2 \%$, с пятнадцатых по тридцатые - на $19,8 \%$, с тридцатых по шестидесятые - на $16,6 \%$ (p<0,001). С первых же по шестидесятые сутки исследования уменьшение показателя составило $21,7 \%$ ( $<00,001)$.

Введение ЭЭП сопровождалось увеличением количества клеток в одной собственной железе фундального отдела желудка крыс, в сравнении с аналогичным показателем интактных крыс контрольной группы, на первые, седьмые и пятнадцатые сутки исследования на $30,6 \%, 25,2 \%$ и на $19,9 \%$ соответственно $(\mathrm{p}<0,001)$ (таблица 2$)$. При сопоставлении количества клеток в одной собственной железе фундального отдела желудка крыс в разные сроки по завершении применения ЭЭП было обнаружено его уменьшение с первых по тридцатые сутки на $24,7 \%(\mathrm{p}<0,001)$, а также с первых по шестидесятые сутки на $23,4 \%$ $(\mathrm{p}<0,01)$.

Количество пристеночных экзокриноцитов в одной собственной железе фундального отдела желудка крыс, которым вводили ЭЭП, увеличивалось в сравнении с соответствующим показателем у крыс контрольной группы на первые и седьмые сутки наблюдения (таблица 3). На первые сутки увеличение составило $16,0 \%(\mathrm{p}<0,01)$, а на седьмые $-7,8 \%(\mathrm{p}<0,05)$. При сопоставлении значений количества присте-ночных экзокриноцитов в одной собственной железе крыс, перенесших введение ЭЭП, в разные сроки исследования было установлено, что с первых по тридцатые сутки этот показатель постепенно уменьшался на $20,2 \%$ $(\mathrm{p}<0,01)$.

Таблица 1

Высота собственных желез слизистой оболочки фундального отдела желудка крыс, получавших ЭЭП ( $\mathrm{M} \pm \mathrm{m}$, мкм)

\begin{tabular}{|c|c|c|c|}
\hline \multirow{2}{*}{$\begin{array}{c}\text { Сутки } \\
\text { исследования }\end{array}$} & \multirow{2}{*}{$\begin{array}{c}\text { Количество } \\
\text { крыс } \\
\text { в группе }\end{array}$} & \multicolumn{2}{|c|}{ Высота собственных желез слизистой оболочки фундального отдела желудка } \\
\hline & & Контрольная группа & После воздействия ЭЭП \\
\hline 1 & $\mathrm{n}=6$ & $591,54 \pm 8,25$ & $760,84 \pm 6,28^{*}$ \\
\hline 7 & $\mathrm{n}=6$ & $577,48 \pm 14,30$ & $743,30 \pm 15,49^{*}$ \\
\hline 15 & $\mathrm{n}=6$ & $605,93 \pm 2,50^{\mathrm{x}}$ & $713,88 \pm 9,60 *^{x}$ \\
\hline 30 & $\mathrm{n}=6$ & $554,52 \pm 3,89$ & $572,46 \pm 18,91^{x}$ \\
\hline 60 & $\mathrm{n}=6$ & $618,21 \pm 5,19^{\mathrm{x}}$ & $595,65 \pm 17,14^{x}$ \\
\hline
\end{tabular}

Примечание: * $-\mathrm{p}<0,001$ в сравнении с показателями крыс контрольной группы (интактные крысы); ${ }^{\mathrm{x}}-\mathrm{p}<0,001$ в сравнении с другими сроками исследования. 
Количество клеток в одной собственной железе фундального отдела желудка крыс, получавших ЭЭП (M $\pm \mathrm{m})$

\begin{tabular}{|c|c|c|c|}
\hline \multirow{2}{*}{$\begin{array}{c}\text { Сутки } \\
\text { исследования }\end{array}$} & \multirow{2}{*}{$\begin{array}{c}\text { Количество } \\
\text { крыс } \\
\text { в группе }\end{array}$} & \multicolumn{2}{|c|}{ Количество клеток в одной собственной железе фундального отдела желудка } \\
\hline & & Контрольная группа & После воздействия ЭЭП \\
\hline 1 & $\mathrm{n}=6$ & $117,75 \pm 3,06$ & $153,80 \pm 9,67 *$ \\
\hline 7 & $\mathrm{n}=6$ & $115,48 \pm 2,29$ & $144,59 \pm 5,69^{*}$ \\
\hline 15 & $\mathrm{n}=6$ & $118,22 \pm 4,20$ & $141,77 \pm 2,61 *$ \\
\hline 30 & $\mathrm{n}=6$ & $114,72 \pm 4,90$ & $115,81 \pm 3,64^{x}$ \\
\hline 60 & $\mathrm{n}=6$ & $119,61 \pm 4,41$ & $117,83 \pm 7,08^{\mathrm{x}}$ \\
\hline
\end{tabular}

Примечание: * - p<0,001 в сравнении с показателями крыс контрольной группы (интактные крысы); ${ }^{\mathrm{x}}-\mathrm{p}<0,001$ в сравнении с другими сроками исследования.

Таблица 3

Количество пристеночных экзокриноцитов в одной собственной железе слизистой оболочки фундального отдела желудка крыс, получавших ЭЭП (M \pm m)

\begin{tabular}{|c|c|c|c|}
\hline \multirow{2}{*}{$\begin{array}{c}\text { Сутки } \\
\text { исследования }\end{array}$} & \multirow{2}{*}{$\begin{array}{c}\text { Количество } \\
\text { крыс } \\
\text { в группе }\end{array}$} & \multicolumn{2}{|c|}{$\begin{array}{c}\text { Количество пристеночных экзокриноцитов в одной собственной железе } \\
\text { слизистой оболочки фундального отдела желудка крыс }\end{array}$} \\
\hline & & Контрольная группа & После воздействия ЭЭП \\
\hline 1 & $\mathrm{n}=6$ & $35,68 \pm 2,12$ & $41,40 \pm 2,41^{*}$ \\
\hline 7 & $\mathrm{n}=6$ & $35,47 \pm 1,14$ & $38,25 \pm 1,47^{*}$ \\
\hline 15 & $\mathrm{n}=6$ & $36,34 \pm 1,76$ & $37,76 \pm 1,00$ \\
\hline 30 & $\mathrm{n}=6$ & $33,75 \pm 1,85$ & $33,03 \pm 1,93^{\mathrm{x}}$ \\
\hline 60 & $\mathrm{n}=6$ & $34,74 \pm 2,70$ & $34,31 \pm 1,67^{x}$ \\
\hline
\end{tabular}

Примечание: * ${ }^{*}$ p $<0,001$ в сравнении с показателями крыс контрольной группы (интактные крысы); ${ }^{\mathrm{x}}-\mathrm{p}<0,001$ в сравнении с другими сроками исследования.

В период с первых по шестидесятые сутки наблюдения уменьшение количества пристеночных экзокриноцитов составило $17,1 \%$ $(\mathrm{p}<0,05)$.

Учитывая результаты исследования, можно сделать следующие выводы:

1. Воздействие ЭЭП приводит к изменениям в структуре слизистой оболочки фундального отдела желудка, которые сохраняются после завершения действия ЭЭП.

2. Под влиянием ЭЭП высота собственных желез и количество клеток в одной собственной железе слизистой оболочки фундального отдела желудка крыс увеличивались с первых по пятнадцатые сутки наблюдения.

3. Количество пристеночных экзокриноцитов в одной собственной железе фундального отдела желудка крыс вследствие влияния ЭЭП увеличивалось в период с первых по седьмые сутки наблюдения. Степень увеличения указанных показателей с течением времени постепенно уменьшалась.

Дальнейшие исследования закономерностей структурных изменений слизистой оболочки желудка под влиянием ЭЭП позволят получить более детальное представление о механизмах действия этого антиоксиданта на состояние желудка.

\section{ЛИТЕРАТУРА}

1. Аруин Л.И. Апоптоз при патологических процессах в органах пищеварения // Клиническая медицина. -2000 . - № 1. - С. 5-10.

2. Высоикий И.Ю. Фармакологическая коррекция нарушений уровня отдельных компонентов митохондриальной и микросомальной электронтранспортных цепей в гепатоцитах при острой токсической гепатопатии, вызванной эпихлоргидрином // Современные проблемы токсикологии. - 2009. - № 3-4. - С. 68.

3. Гречишкина Т.Ф. Структурные изменения слизистой оболочки желудка крыс при поступлении в организм летучих компонентов эпоксидных смол // Вісник Луганського національного педагогічного університету імені Тараса Шевченка. - 2004. - № 4 (72). - С. 15-19.

4. Минак E.H. Изучение действия эхинацеи пурпурной на биохимические показатели при остром тетрахлорметановом гепатите // Лабораторная диагностика. - 2003. - № 1. - С. 51-53.

5. Плужников М.С., Иванов Б.С., Жуманкулов М.С. Клиническое значение процессов перекисного окисления липидов // Вестник оториноларингологии. - 1991. - № 3. - С. 89-91. 